\title{
Inhibition of 195 proteasome-associated deubiquitinases by metal-containing compounds
}

\author{
Ningning Liu ${ }^{1,2}$, Hongbiao Huang ${ }^{1}$, Q. Ping Dou ${ }^{1,3}$, Jinbao Liu ${ }^{1}$ \\ ${ }^{1}$ State Key Lab of Respiratory Disease, Protein Modification and Degradation Lab, Department of Pathophysiology, \\ Guangzhou Medical University, Guangdong, China \\ ${ }^{2}$ Guangzhou Research Institute of Cardiovascular Disease, The Second Affiliated Hospital of Guangzhou Medical University, \\ Guangzhou, Guangdong, People's Republic of China \\ ${ }^{3}$ The Molecular Therapeutics Program, Barbara Ann Karmanos Cancer Institute, and Departments of Oncology, \\ Pharmacology and Pathology, School of Medicine, Wayne State University, Detroit, Michigan, USA
}

Correspondence to: Jinbao Liu, email: jliu@gzhmu.edu.cn

Keywords: 19S-associated deubiquitinases, copper complexes, gold complexes

Received: December 29, $2014 \quad$ Accepted: May 24, 2015

Published: May 31, 2015

This is an open-access article distributed under the terms of the Creative Commons Attribution License, which permits unrestricted use, distribution, and reproduction in any medium, provided the original author and source are credited.

\section{ABSTRACT}

Copper and gold complexes have clinical activity in several diseases including cancer. Recently, we have reported that the anti-cancer activity of copper (II) pyrithione CuPT and gold (I) complex auranofin is associated with targeting the 19S proteasome-associated deubiquitinases (DUBs), UCHL5 and USP14. Here we discuss metal DUB inhibitors in treating cancer and other diseases. (from Editor). Several copper and gold complexes have clinical activity in treating some human diseases including cancer. Recently, we have reported that the anti-cancer activity of copper (II) pyrithione CuPT and gold (I) complex auranofin is tightly associated with their ability to target and inhibit the 195 proteasome-associated deubiquitinases (DUBS), UCHL5 and USP14. In this article we review small molecule inhibitors of DUBs and 195 proteasome-associated DUBs. We then describe and discuss the ubique nature of CuPT and auranofin, which is inhibition of $19 \mathrm{~S}$ proteasome-associated UCHL5 and USP14. We finally suggest the potential to develop novel, specific metal-based DUB inhibitors for treating cancer and other diseases.

\section{INTRODUCTION}

\section{Ubiquitin-proteasome system and copper/gold complexes}

The ubiquitin-proteasome system (UPS) mediates protein degradation through a cascade process. The target protein can be bonded to ubiquitin (Ub) through $\mathrm{Ub}$ activating enzymes (E1), Ub-conjugating enzymes (E2) and Ub-protein ligases (E3). The 26S proteasome, a multisubunit protein complex that exerts function with ATP, contains two 19S proteasomes in both sides and a cylinder-shaped 20S proteasome in the middle. Ubiquitylated protein is degraded by $20 \mathrm{~S}$ proteasome which has three related active proteolytic sites, chymotrypsine-like, trypsine-like and caspase-like. One physiological role of the 19S proteasome is to unfold and remove the Ub chains from the target protein in order to send the protein to $20 \mathrm{~S}$ core [1-3].
Since the proteasome inhibitor bortezomib (Velcade, PS341) has been approved by FDA as a potent anti-multiple myeloma drug, the proteasome-mediated degradation pathway has proven to be an important target for developing novel drugs for the treatment of cancer and other diseases. Our laboratory and others have reported that the chymotrypsinelike activity of the $20 \mathrm{~S}$ proteasome is the important drug target for several medicinal and metal-containing antitumor proteasome inhibitors. Shikonin, a natural naphthoquinone isolated from the traditional Chinese medicine $\mathrm{Zi} \mathrm{Cao,}$ inhibits the proteasome chymotrypsin-like activity in vitro and in vivo, associated with induction of the tumor cell death through accumulation of proapoptotic proteins IkB- $\alpha$, Bax and p27 [4]. Sanggenon C, a natural prenylated flavonoid, inhibits tumor cellular proteasomal chymotrypsin-like activity and cell growth [5]. Gambogic acid, a natural compound derived from Chinese herbs approved by the Chinese Food and Drug Administration for clinical trials in cancer patients, produces 
tissue-specific proteasome chymotrypsin-like inhibition and tumor-specific toxicity [6] and overcomes imatinib resistance by inducing proteasome inhibition and caspase-dependent Bcr-Abl downregulation [7]. Several copper compounds such as NCI-109268 and bis-8-hydroxyquinoline copper(II) [Cu(8-OHQ)(2)] can inhibit the chymotrypsin-like activity of purified 20S proteasome and cellular proteasome activity [8]. Disulfiram, a member of the dithiocarbamate family capable of binding copper and an inhibitor of aldehyde dehydrogenase, inhibits proteasome chymotrypsin-like activity in copper-containing tumor cells and xenografts [9]. Clioquinol, a therapeutic agent for Alzheimer's disease, is able to target tumor proteasome in vivo in a copperdependent manner, resulting in formation of an active AR inhibitor and apoptosis inducer that is responsible for its observed antiprostate tumor effect [10]. Gallium(III)containing complexes show promising antineoplastic effects particularly in lymphomas and bladder cancer by acting as potent proteasome inhibitors [11]. The copper complexes binding with 1,10-phenanthroline as the third ligand also serve as potent, selective proteasome inhibitors and apoptosis inducers in human tumor cells, and these ternary complexes may be good potential antitumor drugs [12]. Some synthetic gold(III) dithiocarbamate complex shows the inhibitory activity to a purified $20 \mathrm{~S}$ proteasome and $26 \mathrm{~S}$ proteasome in intact highly metastatic breast cancer cells with the accumulation of ubiquitinated proteins and induction of apoptosis, which is also exhibiting inhibition in breast tumorbearing nude mice [13-14]. Two gold(III)-dithiocarbamato peptidomimetics target the MDA-MB-231 (resistant to cisplatin) breast cancer cell cultures and xenografts though proteasome chymotrypsin-like activity inhibition [15].

From the above observations we believed that metal complexes act as the potential antitumor drugs via targeting proteasome activity. In fact, it has been known that the platinum-based drug cisplatin, one of the most effective chemotherapy agents, exerts the antitumor activity. Furthermore, metal complexes have already been used as the potential antitumor drugs for treatment of various human diseases for centuries [16-18].

Copper has a long history in medical application [19]. Copper in cells is proved to trigger the ubiquitin aggregation [20], and binds certain types of organic ligands to form potent proteasome inhibitors and induce apoptosis in vitro and in vivo [8]. The reduced $\left(\mathrm{Cu}^{+}\right)$ or oxidized $\left(\mathrm{Cu}^{2+}\right)$ state of copper drives its diverse roles in structure and catalysis. Since $\mathrm{Cu}^{+}$has an affinity for thiol and thioether groups and $\mathrm{Cu}^{2+}$ exhibits a preferred coordination to oxygen or imidazole nitrogen groups, these metal ions can participate in a wide spectrum of interactions with proteins to exert diverse structures and biochemical reactions [21]. Phosphine $\mathrm{Cu}^{+}$complex (CP) as an efficient in vitro antitumor agent could induce ER-stress-mediated apoptosis in colon cancer cells and primary cells from B-acute lymphoblastic leukemia patients, and sensitize B-acute lymphoblastic leukemia cells to chemotherapeutic agents, associated with inhibition of all three proteolytic enzyme activities of the
20S proteasome [22-23]. $\mathrm{Cu}^{2+}$ appears to induce fibril-fibril association without affecting fibrillar structure of Alzheimer's disease amyloid-beta peptide [24]. The thioxotriazole $\mathrm{Cu}^{2+}$ complex A0 exhibits a significantly higher cytotoxic activity in the human fibrosarcoma cells with non-apoptotic programmed cell death [25]. A0 also causes paraptotic cell death via eIF $2 \alpha$ phosphorylation and unfolded protein response (UPR) in human cancer cells [26].

Gold also has a long history as a potent therapeutic agent [27-31]. Gold (I) compounds such as auranofin have been used clinically to treat rheumatoid arthritis for many years. However, auranofin also exerts immunosuppressive activity which may through inhibiting MHC-restricted antigen presentation in professional antigen-presenting cells [32], and exhibits potent antimalarial effects by causing severe intracellular oxidative stress in vitro [33]. Auranofin can inhibit thioredoxin reductase-1, serving as a promising approach for lung cancer therapy [34]. Auranofin induces ERstress response in cultured and primary chronic lymphocytic leukemia cells [35]. Auranofin also increases levels of proapoptotic proteins Bax and Bim and reduces anti-apoptotic protein Bcl-2 in ovarian carcinoma cells, and activates caspase-3-mediated apoptosis in a FOXO3-dependent manner [36]. Gold(III) and organogold(III) compounds have been reported as potential antitumor agents [37-39]. Two gold(III) methylsarcosinedithiocarbamate derivatives, combining cytostatic and apoptotic activity with reduced nephrotoxicity for the management of myeloid leukemia, can down-regulate Bcl-2 and upregulate Bax to induce cell death [40]. Iminophosphorane-organogold(III) complexes can induce tumor cell death through mitochondrial ROS production [41].

\section{Deubiquitinases (DUBs) and their small molecules inhibitors}

The UPS includes the large family of DUBs. DUBs mediate the deubiquitination of the proteolytic process of the UPS. DUBs belong to the superfamily of proteases. The human genome encodes at least 98 DUBs which belongs to 6 subfamilies based on sequence and structural similarity: ubiquitin carboxy-terminal hydrolases (UCHs), ubiquitinspecific proteases (USPs), ovarian-tumor proteases (OTUs), Machado-Joseph disease protein domain proteases, JAMM/ MPN domain-associated metallopeptidases (JAMMs) and monocyte chemotactic protein-induced protein (MCPIP) family [42-44]. All these are cysteine proteases except JAMMs family, which belongs to the metalloproteases catalytic class.

A number of DUBs have been shown to play a role in the process of diseases. UCHL1 is associated with a rare form of Parkinsonism and its accumulation is likely to play a pathological role in inclusion formation in Parkinson's diseases [45]. Inhibition of USP1 leads to hyperaccumulation of monoubiquitinated FANCD2, a protein that appears to be critical in the repair of DNA damage [46]. High expression 
levels of USP28 are found in colon and breast carcinomas, associated with the stabilization of MYC in the nucleus for tumor cell proliferation [47]. USP2 stabilizes cyclin D1 in order to maintain human cancer cell growth; targeting USP2 is therefore an effective approach to induce growth suppression of cancer cells addicted to cyclin D1 expression [48]. USP9X can stabilize MCL-1 to promote tumor cell survival through removing the Lys 48-linked polyubiquitin chains that normally mark MCL-1 for proteasomal degradation, which serves as a prognostic and therapeutic target of human malignancies [49]. Cylindromatosis tumor suppressor gene (CYLD), a member of the USPs family, was first identified as a tumor suppressor gene in the regulation of $\mathrm{NF}-\kappa \mathrm{B}$ activation [50]. A20, a member of the OTUs family, was first discovered after TNF-alpha treatment from mice deficient for A20 developed severe inflammation related with hypersensitivity to TNF-alpha [51].

Some DUB inhibitors have been reported to influence specific DUBs with diverse function. Ubiquitin aldehyde (Ubal) and ubiquitin vinylsulfone (UbVS) were used previously as irreversible DUB inhibitors mainly for the purpose of analysis of the three-dimensional structure of DUB enzymes, because their high molecular weight and limited specificity restrict their development to therapeutic drugs [52-53]. WP1130 is a small molecule that directly inhibits USP9X, USP5, USP14 and UCH37, all known as regulators of survival protein stability and $26 \mathrm{~S}$ proteasome function; WP1130-mediated DUBs' inhibition downregulates the antiapoptotic protein MCL-1 and upregulates the proapoptotic proteins p53 [54]. WP1130-induced unfolded protein response (UPR) blocks specific viral infection via activating the X-box binding protein-1 (XBP-1) in murine macrophages, suggesting its potential use for broad spectrum antiviral therapies [55]. P5091 is a small molecule-selective inhibitor of USP7, discovered by using a ubiquitin-phospholipase $\mathrm{A}_{2}$ enzyme reporter assay in a high throughput screening for inhibitors of USP7 from a diversitybased library of small molecules. Supported by in vivo and in vitro data, P5091 acts as a potential anti-multiple myeloma drug to overcome bortezomib resistance [56]. P22077, another USP7 inhibitor, stabilizes p53 by inducing HDM2 protein degradation in neuroblastoma (NB) cells and inhibits the xenograft growth of three cell lines in the NB mouse model [57]. PR-619 has been characterized as a broad-range, reversible DUB inhibitor of ubiquitin isopeptidases with potential to be developed into an anticancer chemotherapeutic agent. PR-619 also affects the microtubule network and causes protein aggregate formation in neural cells with implications in neurodegerative diseases $[58,59]$.

\section{S proteasome-associated DUBs and their inhibitors}

There are three important DUBs associated with the 19S proteasome, the JAMM family member POH1 (also known as RPN11/pda1/S13/mpr1), the USP family member
USP14 and the UCHs family member UCHL5 (also known as $\mathrm{UCH} 37) . \mathrm{POH} 1$ is a $\mathrm{Zn}$-dependent metalloprotease, whereas USP14 and UCHL5 are cysteine proteases [60].

$\mathrm{POH} 1$ is responsible for substrate deubiquitination during protein degradation in proteasome [61]. Overexpression of POH1 in mammalian cells may help tumor cell escape from chemotherapeutic agents through increased cell growth and resistance to cytotoxic drugs [62]. POH1 contributes to the regulation of c-Jun ubiqutination, stability and subcellular localization, suggesting a novel mechanism of c-Jun regulation in mammalian cells [63]. As a required enzymatic subunit of the 19S proteasome, the JAMM motif of POH1 is essential for cell viability [64]. It appears that $\mathrm{POH} 1$ cleaves at the base of the ubiquitin chain where it is linked to the target protein, whereas USP14 and UCHL5 mediate a stepwise removal of ubiquitin from the protein by disassembling the chain from its distal tip [65]. The RNAi of UCHL5 or USP14 alone does not affect cell growth and proteasome composition but accelerates cellular protein degradation; however, RNAi of both UCHL5 and USP14 can inhibit cellular protein degradation. Thus proper proteasomal processing of ubiquitylated substrates needs $\mathrm{POH} 1$ plus either UCHL5 or USP14 [66].

USP14 regulates both the nature and magnitude of proteasome activity [67]. The role of USP14 in disease development remains unclear. In USP14-deficient ax (J) mice, the nervous systemic endogenous tau and ataxin-3 levels decrease and the phosphorylated tau levels increase which is accompanied by increased levels of activated phosphoAkt, phosphorylated MAPKs, and inactivated phosphoGSK $3 \beta$, begging a better understanding of the treatment with chronic neurological diseases through the cellular pathways regulated by the proteasome [68]. The USP14 deficiency in the $\operatorname{ax}(\mathrm{J})$ mice contributes to diseases characterized by synaptic dysfunction [69]. Genetic and chemical suppression of USP14 activity caused an increase in Dishevelled (Dvl) polyubiquitination and significantly impaired downstream Wnt signaling, suggesting an oncogenic role for USP14 through Wnt/ $\beta$-catenin signaling enhancement [70]. USP14 binding to the IRE1 protein for ER stress regulation indicates an important role in mutant Huntingtin-induced cell toxicity and the murine norovirus-caused infections [55, 71]. The USP14 expression is upregulated in non-small cell lung cancer (NSCLC) cells, especially in adenocarcinoma cells, suggesting its tumor-promoting function. Downregulation of USP14 expression is related to $\beta$-catenin degradation that blocks the NSCLC cell cycle progression [72]. Up-expression of miR-4782-3p is related with favorable prognosis in NSCLC cells through decreasing the USP14 expression [73]. Although USP14 usually plays an inhibitory role in protein degradation, overexpression of USP14 induced I- $\kappa \mathrm{B}$ degradation by linking RelA, the binding partner of $\mathrm{I}-\kappa \mathrm{B}$, leading to increased cytokine release in lung epithelial cells [74].

UCHL5 is responsible for the ubiquitin isopeptidase activity in the $19 \mathrm{~S}$ proteasome regulatory complex, acting as the constituent subunit like the POH1 subunit. Rpn13 
binds the carboxy-terminal tail of UCHL5 in order to recruit it into proteasome through binding to Rpn2 subunit of the 19S complex [75-77]. Rpn13 may involve the iNOS/IкB- $\alpha$ degradation and the interaction of $\mathrm{NOS} / \mathrm{I} \kappa \mathrm{B}-\alpha$ with UCHL5, indicating the iNOS/IкB- $\alpha$ as the substrates for the Rpn13/ UCHL5 [78]. UCHL5 interacts with Smads and reverses Smurf-mediated ubiqutination, and it can also deubiquitinate and stabilize the type I TGF- $\beta$ receptor in cells [79]. UCHL5 protein expression is increased and required in high glucose-induced mouse mesangial cells in a possible PI3K-dependent fashion. UCHL5 shRNA attenuates high glucose-induced TGF- $\beta$ R1 protein expression, TGF- $\beta$ R1 protein deubiquitination, p21 (WAF1) fibronectin protein expression, and cell hypertrophy [80]. UCHL5 may play an important role in apoptotic death through altering Bax/ Bcl-2 ratio and caspase-9/3 activities in A549 cells [81]. Overexpression of UCHL5 in hepatocellular carcinoma (HCC) cancerous cells can promote cell migration and invasion through interacting and deubiquitinating PRP19, an essential RNA splicing factor. UCHL5 expressing in vitro and in vivo suggests its predictor role for $\mathrm{HCC}$ recurrence after curative resection [82].

IU1 is a specific inhibitor of USP14 vs. other human DUBs including 19S proteasome DUBs, which is also able to enhance the proteasome activity [83]. This small-molecule inhibitor can prevent ventilator-induced lung injury in rats by attenuate intrapulmonary inflammatory response [84]. IU1 also inhibits Dengue virus replication, providing new targets for therapeutic intervention against viruses from multiple families [85]. Based on the structure of IU1, a group of tricyclic heterocyclics have been developed to specifically inhibit USP14 activity. These compounds could accelerate the degradation of abnormal and/or misfolded proteins in the cells by targeting USP14 [86].

Another small molecule b-AP15 is first reported as a new tumor cell inhibitor to $19 \mathrm{~S}$ regulatory-particle-associated deubiquitinases USP14 and UCHL5 activity without affecting 20S core-particle-associated proteolytic activity [87]. b-AP15 triggers apoptosis in the multiple myeloma (MM) cells and patient MM cells through caspase activation and overcomes 20S proteasome inhibitor bortezomib resistance [88-89]. Exposure of tumor cell lines to b-AP15 resulted in increased TRAIL-R2 expression and enhanced sensitivity to TRAILmediated apoptosis and cell death in vitro and in vivo [90]. b-AP15-induced sensitization to TRAIL-mediated apoptosis could be used as a novel strategy to augment the anticancer effects of adoptively infused NK and T cells in patients with cancer [91]. The effect of b-AP15 in cells can be impaired by the antioxidant $\mathrm{N}$-ethylmaleimide that could cause inhibition of selenoprotein thioredoxin reductase to trigger oxidative stress [92]. Azepan-4-ones, similar to b-AP15 also possess the inhibitory activity to USP14 and UCHL5, but this set of compounds do not affect non-proteasomal DUBs. They are described as effective compounds for the treatment of tumor resistance especially the bortezomib-refractory tumors caused by over-expressing Bcl-2 protein [93].

AC17, a 4-arylidene curcumin analog synthesized by
Zhou et al., serves as an irreversible 19S-associated DUB inhibitor while it does not affect $20 \mathrm{~S}$ proteasome proteolytic activities. However, the AC17 targeting sites in 19S-related DUBs have not been determined. The inhibition of $19 \mathrm{~S}$ proteasome DUBs by AC17 suppresses cell proliferation by blocking NF- $\kappa \mathrm{B}$ activation and increasing p53, MDM2 and p21 expression in both human lung adenocarcinoma A549 cells and xenograft model [94].

\section{CuPT and auranofin on 19S proteasome- associated UCHL5 and USP14}

The application of the metal complex proteasome inhibitors in cancer therapy suggests that targeting the UPS by inhibiting the proteasome-associated DUBs may have potential uses clinically. Consistently, a reported panel of 2-phenylpyrindine gold(III) complexes containing a dithiocarbamate ligand display a promising inhibitory effect on UCHs and significant tumor cell cytotoxicity [95]. Two important recent reports on proteasome-associated metal complexes as DUBs inhibitors display promising in vivo anti-cancer activities against several cancers, further lending support to this view (Table 1) [96-97].

Copper pyrithione (CuPT) is an alternative to tributyltin for antifouling paint biocides [98]. We investigate the inhibitory effect of CuPT on USP14/UCHL5 activity and the relationship to cellular apoptosis in vitro and in vivo, towards the goal of developing novel DUB inhibitors and clinical anticancer strategy. We first compare the effect of $\mathrm{PT} / \mathrm{CuCl}_{2}$ alone and 2:1 $\mathrm{PT} / \mathrm{CuCl}_{2}$ combination on a number of tumor cell lines, including human breast $\mathrm{MCF}-7$, human multiple myeloma U266 and NCI-H929, and human hepatoma SMMC-7721. The results show that the combination of $\mathrm{PT}$ and $\mathrm{CuCl}_{2}$ induces cytotoxicity much more effectively than PT or $\mathrm{CuCl}_{2}$ along. However, we found that the $\mathrm{PT}+\mathrm{CuCl}_{2}$, but not PT $+\mathrm{H}_{2} \mathrm{O}_{2}$ induced the UPS inhibition. We also observed that the combination (CuPT) of $1 \mathrm{Cu}$ molecule and 2 PTs induced cytotoxicity in multiple cancer cell lines $\left(24 \mathrm{~h} \mathrm{IC}_{50}\right.$ values: MCF7 $0.375 \mu \mathrm{M}$, U266 0.130 $\mu \mathrm{M}$, and HepG2 $0.495 \mu \mathrm{M}$ ) and primary cancer cells from patients with acute myeloid leukemia (AML) (average 24h IC $50=57.03 \mathrm{nM}$ while CTR $=101.08 \mathrm{nM}$ ). CuPT induced UPS malfunction which is similar to the mixture of PT and copper in human hepatoma HepG2 cells and GFPu-HEK293 cells with cellular ubiquitinated and GFP protein aggregation. It can only inhibit the chymotrypsine-like (but not caspase or trypsin-like activity) at high doses $(>1 \mu \mathrm{M})$ of purified $20 \mathrm{~S}$ proteasome under cell-free condition. Interestingly, low concentration of CuPT exerts inhibition on 19S-associated DUBs, USP14 and UCHL5. The computational study supports the docking affinity between CuPT and the 19S-associated DUBs and suggests its relationship with inhibiting USP14 and UCHL5 activities. CuPT $(0.5 \mu \mathrm{M})$ can inhibit the DUB activity significantly on the purified $26 \mathrm{~S}$ proteasome as the same as the pan DUB inhibitor NEM (with the concentration at $2 \mathrm{mM})$. Also, CuPT $(0.5$ and $1 \mu \mathrm{M})$ 


\begin{tabular}{|c|c|c|c|c|c|}
\hline Inhibitor & $\begin{array}{l}\text { 19S-associated } \\
\text { DUB/s }\end{array}$ & Substrate/s & $\begin{array}{l}\text { First-reported } \\
\text { Function }\end{array}$ & $\begin{array}{l}\text { Related cell lines and tumor } \\
\text { model }\end{array}$ & References \\
\hline WP1130 & $\begin{array}{l}\text { UCHL5, } \\
\text { USP14 } \\
\text { (and USP9X, } \\
\text { USP5) }\end{array}$ & MCL-1, p53 & $\begin{array}{l}\text { Induces tumor } \\
\text { cells apoptosis } \\
\text { through selectively } \\
\text { inhibiting DUBs }\end{array}$ & MM1.S, Z138, HEK293T & {$[54]$} \\
\hline IU1 & USP14 & $\begin{array}{l}\text { Tau, TDP-43, } \\
\text { cODC-EGFP }\end{array}$ & $\begin{array}{l}\text { Accelerates the } \\
\text { degradation of } \\
\text { oxidized proteins } \\
\text { and enhances } \\
\text { resistance to } \\
\text { oxidative stress } \\
\text { in vitro }\end{array}$ & $\begin{array}{l}\text { Primary mouse } \\
\text { embryonic (MEFs), } \\
\text { HEK293, HeLa }\end{array}$ & [83] \\
\hline $\begin{array}{l}\text { Tricyclic } \\
\text { heterocyclics } \\
\text { (IU2-6) }\end{array}$ & USP14 & Tau & $\begin{array}{l}\text { Accelerate the } \\
\text { degradation of } \\
\text { abnormal and/or } \\
\text { misfolded proteins } \\
\text { in cells }\end{array}$ & MEF & [86] \\
\hline b-AP15 & $\begin{array}{l}\text { UCHL5, } \\
\text { USP14 }\end{array}$ & $\begin{array}{l}\text { p53, ODC-1, } \\
\text { CDKN1B, } \\
\text { CDKN1A, } \\
\text { Caspase-3, PARP }\end{array}$ & $\begin{array}{l}\text { Inhibits tumor } \\
\text { progression in vitro } \\
\text { and in vivo }\end{array}$ & $\begin{array}{l}\text { HCT-116, SCID mice } \\
\text { with FaDu human tumor } \\
\text { xenografts, C57BL/6J mice } \\
\text { with syngenic LLC tumor, } \\
\text { BALB/C mice with orthotopic } \\
\text { breast carcinomas (4T1), } \\
\text { Xenograft-derived CK18 in } \\
\text { circulation }\end{array}$ & [87] \\
\hline Azepan-4-ones & $\begin{array}{l}\text { UCHL5, } \\
\text { USP14 }\end{array}$ & Bcl-2 & $\begin{array}{l}\text { Inhibit the } \\
\text { refractory tumor }\end{array}$ & $\begin{array}{l}\text { Multiple myeloma and other } \\
\text { solid tumor malignancies like } \\
\text { lung, prostate, colon, ovary, } \\
\text { pancreas, breast, neck and } \\
\text { head cancers }\end{array}$ & [93] \\
\hline $\mathrm{AC} 17$ & $\begin{array}{l}\text { 19S-associated } \\
\text { DUBs }\end{array}$ & $\begin{array}{l}\text { NF-kB, p53, } \\
\text { MDM2, p21 }\end{array}$ & $\begin{array}{l}\text { Suppresses the cell } \\
\text { proliferation. }\end{array}$ & $\begin{array}{l}\text { A549, BALB/C nude mice } \\
\text { with A549 xenograft. }\end{array}$ & [94] \\
\hline AuIII & $\begin{array}{l}\text { UCHL1-C } \\
\text { UCHL3-C } \\
\text { UCHL5-C } \\
\text { (C: a cysteine } \\
\text { active site) }\end{array}$ & $\begin{array}{l}\text { Caspase-7, } \\
\text { PARP }\end{array}$ & $\begin{array}{l}\text { induces } \\
\text { cell-cycle arrest, } \\
\text { apoptosis and } \\
\text { anti-angiogenic } \\
\text { property in breast } \\
\text { cancer cells }\end{array}$ & $\begin{array}{l}\text { MCF-7, MDA-MB-231, } \\
\text { HeLa, MIHA }\end{array}$ & [95] \\
\hline $\mathrm{CuPT}$ & $\begin{array}{l}\text { UCHL5, } \\
\text { USP14 }\end{array}$ & $\begin{array}{l}\text { p21, p27, Bax, } \\
\text { I B- } \alpha, \text { PARP, } \\
\text { Caspase-3, } \\
\text { Caspase-9, } \\
\text { Caspase- } 8\end{array}$ & $\begin{array}{l}\text { Selectively inhibits } \\
\text { tumor growth } \\
\text { in vivo and induces } \\
\text { cytotoxicity } \\
\text { in vitro and ex vivo }\end{array}$ & $\begin{array}{l}\text { MCF-7, HepG2, U266, } \\
\text { NCI-H929, GFPu-HEK293, } \\
\text { Primary acute myeloid } \\
\text { leukemia cells (AML), } \\
\text { BALB/C nude mice with } \\
\text { HepG2/NCI-H929 xenografts }\end{array}$ & [96] \\
\hline Auranofin & $\begin{array}{l}\text { UCHL5, } \\
\text { USP14 }\end{array}$ & $\begin{array}{l}\text { с-Jun, p21, } \\
\text { IкB- } \alpha, \text { NF-кB, } \\
\text { CHOP, } \\
\text { Caspase-3,8,9,12, } \\
\text { PARP }\end{array}$ & $\begin{array}{l}\text { Inhibits tumor } \\
\text { growth in vivo } \\
\text { and induces } \\
\text { cytotoxicity } \\
\text { in vitro and ex vivo }\end{array}$ & $\begin{array}{l}\text { MCF-7, HepG2, } \\
\text { GFPu-HEK293, Primary } \\
\text { acute myeloid leukemia } \\
\text { cells (AML), BAB/C nude } \\
\text { mice with HepG2/MCF-7 } \\
\text { xenografts }\end{array}$ & [97] \\
\hline
\end{tabular}


blocks 26S proteasome-cleaved K48-linked Ub chains and is able to compete with UbVS's binding with both USP14 and UCHL5 in a dose-dependent manner. Daily treatment of mice bearing HepG2 and NCI-H929 xenografts with $2.5 \mathrm{mg}$ / $\mathrm{kg} /$ day CuPT for 15 and 5 days resulted in significant tumor growth inhibition. Associated with this growth inhibition, a significant accumulation of ubiquitinated proteins, K48linked proteins, p21, p27, Bax and IкB- $\alpha$ are detected.

Auranofin, a gold-containing compound, is clinically used to cure rheumatic arthritis, and recently approved by US food and drug administration for phase II clinical trial to treat cancer. We report for the first time that this clinically used metal complex drug auranofin is a specific inhibitor of the 19S-associated DUBs, USP14 and UCHL5 with promising antitumor effects. We showed that auranofin potently inhibited proliferation of two tumor cell lines, HepG2 and MCF-7, with $24 \mathrm{~h} \mathrm{IC}_{50}$ values of $0.43 \mu \mathrm{M}$ and $1.50 \mu \mathrm{M}$, $48 \mathrm{~h} \mathrm{IC}_{50}$ of $0.17 \mu \mathrm{M}$ and $0.41 \mu \mathrm{M}$, respectively. Moreover, auranofin treatment for $24 \mathrm{~h}$ induces apoptotic morphological changes in HepG2 (at $0.25 \mu \mathrm{M})$ and MCF-7 $(0.5 \mu \mathrm{M})$ cells. The flow cytometry data also supports the results observed with fluorescence microscopy. Apoptotic specific changes in caspase and PARP proteins are showed in dose-dependent manner after auranofin treatment, demonstrating that the auranofin-triggered apoptosis is related with caspase activation. Next, we found that auranofin at $0.5 \mu \mathrm{M}$ for $3 \mathrm{~h}$ induces marked increases in total, K48- and K63-linked ubiquitinated proteins, indicating its UPS inhibitory effect. $\mathrm{GFPu}$ proteins and fluorescent images also supported the inhibitory effect of auranofin. The proteasome substrate proteins p21 and c-Jun increase after 9h treatment of auranofin. Importantly, we observed that the K48-linked accumulation induced by therapeutic dose of auranofin $(0.5 \mu \mathrm{M})$ is similar to bortezomib at dose between 20 and $40 \mathrm{nM}$ in K562 cells. These results indicate that a therapeutic dose of auranofin can achieve bortezomib's UPS inhibitory effect. The computational molecular docking, DUB activity, K48-linked Ub chains cleavage and HA-UbVS (HA-tagged ubiquitin-Vinyl Sulfone, which covalently binds to the active sites of the cysteine proteasome families of DUBs) competitive binding experiments are all implemented to prove auranofin's inhibitory activity to $19 \mathrm{~S}$-associated DUBs. The computational model also indicates that an active metabolite of auranofin can inhibit UCHL5 and USP14.

$\mathrm{Ub}-\mathrm{AMC}$ is a fluorogenic substrate for a wide range of DUBs including UCHs and USPs. Using Ub-AMC as a DUB substrate, auranofin slightly inhibits the total cytoplasmic DUB activities while completely inhibits the purified $26 \mathrm{~S}$ proteasome-associated DUB activities at $2 \mu \mathrm{M}$ (as the same effect as $2 \mathrm{mM}$ NEM). We used NAC, a thiol-containing compound, to block the active site of auranofin and found NAC recovers most auranofin-mediated DUB inhibition to purified 26S proteasome, which confirms the computational model results that auranofin targets proteasome-associated UCHL5 and USP14. K48-linked Ub chains cleavage is partially blocked by auranofin in a dose-dependent manner. HA-UbVS pretreatment of auranofin could bind the HA- tagged UbVS in the purified $26 \mathrm{~S}$ proteasome, supporting that auranofin inhibits UCHL5 and USP14. NAC completely reverses auranofin-induced Ub-prs accumulation, caspase activation and PARP cleavage in HepG2 and MCF-7 cells which indicates that the proteasome inhibition is required for auranofin-induced cytotoxicity.

To preclude the ROS generation-induced cell death, we use Tbhq, a phenol-containing antioxidant that cannot bind the active atom site of auranofin, to scavenge auranofin-mediated ROS generation while not blocking auranofin-mediated proteasome inhibition and PARP cleavage. Auranofin also interferes with multiple proteasome-related signal proteins such as CHOP, caspase $12, \mathrm{I} \kappa \mathrm{B}-\alpha$ and NF- $\mathrm{B}$ p65. Daily treatment of mice bearing $\mathrm{HepG} 2$ and $\mathrm{MCF}-7$ xenografts with $6 \mathrm{mg} / \mathrm{kg} /$ day auranofin for 15 and 21 days resulted in significant tumor growth inhibition. Associated with this growth inhibition, a significant accumulation of ubiquitinated proteins, Ub-prs, K48/K63-linked proteins, c-Jun, p21 are observed that shows the auranofin-mediated tumor growth and proteasome function inhibition. Moreover, auranofin can selectively induce cytotoxicity in primary monocytes from patients with AML (average $24 \mathrm{~h} \mathrm{IC50}=0.159 \mu \mathrm{M}$ while $\mathrm{CTR}=0.622 \mu \mathrm{M})$. Furthermore, our recent study reveals that auranofin overcomes Imatinib mesylate resistance through both Bcr/Abl-dependent and -independent mechanisms, and proteasome inhibition but not ROS is required for auranofininduced caspase activation and apoptosis [99].

Therefore, CuPT can potently inhibit the 19S proteasome-associated UCHL5 and USP14 DUB activities at $0.5 \mu \mathrm{M}$ dose, while it can also directly inhibit $20 \mathrm{~S}$ proteasome activities at relatively higher doses than their cytotoxic doses in the cell. The latter inhibition might be related to the direct copper binding to proteasome peptidase subunits in the cell. However, under our experimental conditions, auranofin does not inhibit the activities of chymotrypsin-like, trypsin-like or caspase-like activities of $20 \mathrm{~S}$ proteasomes which is different from the $20 \mathrm{~S}$ proteasome inhibitors such as bortezomib. We suggest that Auranofin is the first DUB inhibitor reported to treat human disease in clinical use. We are currently using various complexes of metals including cadmium, zinc, nickel and platinum containing the same chelating ligand pyrithione to compare their effects on the UPS. The results of these experiments might be able to lead to a discovery of the clinical potential metal-based proteasome inhibitors for cancer therapy.

\section{CONCLUSIONS AND OUTLOOKS}

In summary, we suggest the applications of the copper/ gold complexes as a class inhibitors of deubiquitinates including the 19S proteasome-associated deubiquitinases. We have demonstrated that $\mathrm{CuPT}$ and auranofin are the novel metal inhibitors of UCHL5 and USP14 of the 19S proteasome by using several tumor models, including hematological malignancies, several solid tumor models and primary cells of the acute myeloid leukemia patients. We expect that the 
metal complexes could be developed to the potent inhibitors of $19 \mathrm{~S}$ proteasome-associated deubiquitinases and be used for treating cancer and many other human diseases.

\section{ACKNOWLEDGEMENT}

This work was supported in part by the National High Technology Research and Development Program of China (2006AA02Z4B5), NSFC (81272451/H1609, 81472762/ H1609), MOE (20134423110002), Guangdong Key Laboratory of Urology (2010A060801016) (to J.L.).

\section{CONFLICT OF INTEREST}

The authors declare no conflict of interest.

\section{REFERENCES}

1. Voges D, Zwickl P and Baumeister W. The 26S proteasome: a molecular machine designed for controlled proteolysis. Annual review of biochemistry. 1999; 68:1015-1068.

2. Glickman $\mathrm{MH}$ and Ciechanover A. The ubiquitin-proteasome proteolytic pathway: destruction for the sake of construction. Physiological reviews. 2002; 82(2):373-428.

3. Kish-Trier E and Hill CP. Structural biology of the proteasome. Annual review of biophysics. 2013; 42:29-49.

4. Yang H, Zhou P, Huang H, Chen D, Ma N, Cui QC, Shen S, Dong W, Zhang X, Lian W, Wang X, Dou QP and Liu J. Shikonin exerts antitumor activity via proteasome inhibition and cell death induction in vitro and in vivo. International journal of cancer Journal international du cancer. 2009; 124(10):2450-2459.

5. Huang H, Liu N, Zhao K, Zhu C, Lu X, Li S, Lian W, Zhou P, Dong X, Zhao C, Guo H, Zhang C, Yang C, Wen G, Lu L, Li X, et al. Sanggenon $\mathrm{C}$ decreases tumor cell viability associated with proteasome inhibition. Frontiers in bioscience (Elite edition). 2011; 3:1315-1325.

6. Li X, Liu S, Huang H, Liu N, Zhao C, Liao S, Yang C, Liu Y, Zhao C, Li S, Lu X, Liu C, Guan L, Zhao K, Shi X, Song W, et al. Gambogic acid is a tissue-specific proteasome inhibitor in vitro and in vivo. Cell reports. 2013; 3(1):211-222.

7. Shi X, Chen X, Li X, Lan X, Zhao C, Liu S, Huang H, Liu N, Liao S, Song W, Zhou P, Wang S, Xu L, Wang X, Dou QP and Liu J. Gambogic acid induces apoptosis in imatinib-resistant chronic myeloid leukemia cells via inducing proteasome inhibition and caspase-dependent Bcr-Abl downregulation. Clinical cancer research: an official journal of the American Association for Cancer Research. 2014; 20(1):151-163.

8. Daniel KG, Gupta P, Harbach RH, Guida WC and Dou QP. Organic copper complexes as a new class of proteasome inhibitors and apoptosis inducers in human cancer cells. Biochemical pharmacology. 2004; 67(6):1139-1151.

9. Chen D, Cui QC, Yang H and Dou QP. Disulfiram, a clinically used anti-alcoholism drug and copper-binding agent, induces apoptotic cell death in breast cancer cultures and xenografts via inhibition of the proteasome activity. Cancer research. 2006; 66(21):10425-10433.
10. Chen D, Cui QC, Yang H, Barrea RA, Sarkar FH, Sheng S, Yan B, Reddy GP and Dou QP. Clioquinol, a therapeutic agent for Alzheimer's disease, has proteasome-inhibitory, androgen receptor-suppressing, apoptosis-inducing, and antitumor activities in human prostate cancer cells and xenografts. Cancer research. 2007; 67(4):1636-1644.

11. Chen D, Frezza M, Shakya R, Cui QC, Milacic V, Verani CN and Dou QP. Inhibition of the proteasome activity by gallium(III) complexes contributes to their anti prostate tumor effects. Cancer research. 2007; 67(19):9258-9265.

12. Zhang Z, Bi C, Schmitt SM, Fan Y, Dong L, Zuo J and Dou QP. 1,10-Phenanthroline promotes copper complexes into tumor cells and induces apoptosis by inhibiting the proteasome activity. Journal of biological inorganic chemistry: JBIC: a publication of the Society of Biological Inorganic Chemistry. 2012; 17(8):1257-1267.

13. Milacic V, Chen D, Ronconi L, Landis-Piwowar KR, Fregona D and Dou QP. A novel anticancer gold(III) dithiocarbamate compound inhibits the activity of a purified $20 \mathrm{~S}$ proteasome and $26 \mathrm{~S}$ proteasome in human breast cancer cell cultures and xenografts. Cancer research. 2006; 66(21):10478-10486.

14. Milacic V and Dou QP. The tumor proteasome as a novel target for gold(III) complexes: implications for breast cancer therapy. Coordination chemistry reviews. 2009; 253(11-12):1649-1660.

15. Nardon C, Schmitt SM, Yang H, Zuo J, Fregona D and Dou QP. Gold(III)-dithiocarbamato peptidomimetics in the forefront of the targeted anticancer therapy: preclinical studies against human breast neoplasia. PloS one. 2014; 9(1):e84248.

16. Buac D, Schmitt S, Ventro G, Kona FR and Dou QP. Dithiocarbamate-based coordination compounds as potent proteasome inhibitors in human cancer cells. Mini reviews in medicinal chemistry. 2012; 12(12):1193-1201.

17. Pereira L, Igea A, Canovas B, Dolado I and Nebreda AR. Inhibition of p38 MAPK sensitizes tumour cells to cisplatininduced apoptosis mediated by reactive oxygen species and JNK. EMBO molecular medicine. 2013; 5(11):1759-1774.

18. Kasparkova J, Thibault T, Kostrhunova H, Stepankova J, Vojtiskova M, Muchova T, Midoux P, Malinge JM and Brabec V. Different affinity of nuclear factor-kappa B proteins to DNA modified by antitumor cisplatin and its clinically ineffective trans isomer. The FEBS journal. 2014; 281(5):1393-1408.

19. Wang $\mathrm{T}$ and Guo Z. Copper in medicine: homeostasis, chelation therapy and antitumor drug design. Current medicinal chemistry. 2006; 13(5):525-537.

20. Arnesano F, Scintilla S, Calo V, Bonfrate E, Ingrosso C, Losacco M, Pellegrino T, Rizzarelli E and Natile G. Coppertriggered aggregation of ubiquitin. PloS one. 2009; 4(9):e7052.

21. Festa RA and Thiele DJ. Copper: an essential metal in biology. Current biology: CB. 2011; 21(21):R877-883.

22. Gandin V, Pellei M, Tisato F, Porchia M, Santini C and Marzano C. A novel copper complex induces paraptosis in colon cancer cells via the activation of ER stress signalling. Journal of cellular and molecular medicine. 2012; 16(1):142-151.

23. Bortolozzi R, Viola G, Porcu E, Consolaro F, Marzano C, 
Pellei M, Gandin V and Basso G. A novel copper(I) complex induces ER-stress-mediated apoptosis and sensitizes B-acute lymphoblastic leukemia cells to chemotherapeutic agents. Oncotarget. 2014; 5(15):5978-5991.

24. Karr JW and Szalai VA. $\mathrm{Cu}(\mathrm{II})$ binding to monomeric, oligomeric, and fibrillar forms of the Alzheimer's disease amyloid-beta peptide. Biochemistry. 2008;47(17):5006-5016.

25. Tardito S, Bussolati O, Gaccioli F, Gatti R, Guizzardi S, Uggeri J, Marchio L, Lanfranchi M and Franchi-Gazzola R. Non-apoptotic programmed cell death induced by a copper(II) complex in human fibrosarcoma cells. Histochemistry and cell biology. 2006; 126(4):473-482.

26. Tardito S, Isella C, Medico E, Marchio L, Bevilacqua E, Hatzoglou M, Bussolati $\mathrm{O}$ and Franchi-Gazzola R. The thioxotriazole copper(II) complex A0 induces endoplasmic reticulum stress and paraptotic death in human cancer cells. The Journal of biological chemistry. 2009; 284(36):24306-24319.

27. Benedek TG. The history of gold therapy for tuberculosis. Journal of the history of medicine and allied sciences. 2004; 59(1):50-89.

28. Ronconi L, Giovagnini L, Marzano C, Bettio F, Graziani R, Pilloni $\mathrm{G}$ and Fregona D. Gold dithiocarbamate derivatives as potential antineoplastic agents: design, spectroscopic properties, and in vitro antitumor activity. Inorganic chemistry. 2005; 44(6):1867-1881.

29. Milacic V, Fregona D and Dou QP. Gold complexes as prospective metal-based anticancer drugs. Histology and histopathology. 2008; 23(1):101-108.

30. Norn S, Permin H, Kruse PR and Kruse E. [History of gold-with danish contribution to tuberculosis and rheumatoid arthritis]. Dansk medicinhistorisk arbog. 2011; 39:59-80.

31. Berners-Price SJ and Filipovska A. Gold compounds as therapeutic agents for human diseases. Metallomics: integrated biometal science. 2011; 3(9):863-873.

32. Han S, Kim K, Song Y, Kim H, Kwon J, Lee YH, Lee CK, Lee SJ, Ha N and Kim K. Auranofin, an immunosuppressive drug, inhibits MHC class I and MHC class II pathways of antigen presentation in dendritic cells. Archives of pharmacal research. 2008; 31(3):370-376.

33. Sannella AR, Casini A, Gabbiani C, Messori L, Bilia AR, Vincieri FF, Majori G and Severini C. New uses for old drugs. Auranofin, a clinically established antiarthritic metallodrug, exhibits potent antimalarial effects in vitro: Mechanistic and pharmacological implications. FEBS letters. 2008; 582(6):844-847.

34. Dai B, Yoo SY, Bartholomeusz G, Graham RA, Majidi M, Yan S, Meng J, Ji L, Coombes K, Minna JD, Fang B and Roth JA. KEAP1-dependent synthetic lethality induced by AKT and TXNRD1 inhibitors in lung cancer. Cancer research. 2013; 73(17):5532-5543.

35. Fiskus W, Saba N, Shen M, Ghias M, Liu J, Gupta SD, Chauhan L, Rao R, Gunewardena S, Schorno K, Austin CP, Maddocks K, Byrd J, Melnick A, Huang P, Wiestner A, et al. Auranofin induces lethal oxidative and endoplasmic reticulum stress and exerts potent preclinical activity against chronic lymphocytic leukemia. Cancer research. 2014; 74(9):2520-2532.

36. Park SH, Lee JH, Berek JS and Hu MC. Auranofin displays anticancer activity against ovarian cancer cells through FOXO3 activation independent of $\mathrm{p} 53$. International journal of oncology. 2014; 45(4):1691-1698.

37. Messori L, Marcon G and Orioli P. Gold(III) compounds as new family of anticancer drugs. Bioinorganic chemistry and applications. 2003:177-187.

38. Ronconi L, Marzano C, Zanello P, Corsini M, Miolo G, Macca C, Trevisan A and Fregona D. Gold(III) dithiocarbamate derivatives for the treatment of cancer: solution chemistry, DNA binding, and hemolytic properties. Journal of medicinal chemistry. 2006; 49(5):1648-1657.

39. Casini A, Hartinger C, Gabbiani C, Mini E, Dyson PJ, Keppler BK and Messori L. Gold(III) compounds as anticancer agents: relevance of gold-protein interactions for their mechanism of action. Journal of inorganic biochemistry. 2008; 102(3):564-575.

40. Aldinucci D, Lorenzon D, Stefani L, Giovagnini L, Colombatti A and Fregona D. Antiproliferative and apoptotic effects of two new gold(III) methylsarcosinedithiocarbamate derivatives on human acute myeloid leukemia cells in vitro. Anti-cancer drugs. 2007; 18(3):323-332.

41. Vela L, Contel M, Palomera L, Azaceta G and Marzo I. Iminophosphorane-organogold(III) complexes induce cell death through mitochondrial ROS production. Journal of inorganic biochemistry. 2011; 105(10):1306-1313.

42. Reyes-Turcu FE, Ventii KH and Wilkinson KD. Regulation and cellular roles of ubiquitin-specific deubiquitinating enzymes. Annual review of biochemistry. 2009; 78:363-397.

43. Komander D, Clague MJ and Urbe S. Breaking the chains: structure and function of the deubiquitinases. Nature reviews Molecular cell biology. 2009; 10(8):550-563.

44. Liang J, Saad Y, Lei T, Wang J, Qi D, Yang Q, Kolattukudy PE and $\mathrm{Fu} \mathrm{M}$. MCP-induced protein 1 deubiquitinates TRAF proteins and negatively regulates JNK and NF-kappaB signaling. The Journal of experimental medicine. 2010; 207(13):2959-2973.

45. Ardley HC, Scott GB, Rose SA, Tan NG and Robinson PA. $\mathrm{UCH}-\mathrm{L} 1$ aggresome formation in response to proteasome impairment indicates a role in inclusion formation in Parkinson's disease. Journal of neurochemistry. 2004; 90(2):379-391.

46. Nijman SM, Huang TT, Dirac AM, Brummelkamp TR, Kerkhoven RM, D'Andrea AD and Bernards R. The deubiquitinating enzyme USP1 regulates the Fanconi anemia pathway. Molecular cell. 2005; 17(3):331-339.

47. Popov N, Wanzel M, Madiredjo M, Zhang D, Beijersbergen R, Bernards R, Moll R, Elledge SJ and Eilers M. The ubiquitinspecific protease USP28 is required for MYC stability. Nature cell biology. 2007; 9(7):765-774.

48. Shan J, Zhao W and Gu W. Suppression of cancer cell growth by promoting cyclin D1 degradation. Molecular cell. 2009; 36(3):469-476.

49. Schwickart M, Huang X, Lill JR, Liu J, Ferrando R, French DM, Maecker H, O'Rourke K, Bazan F, EasthamAnderson J, Yue P, Dornan D, Huang DC and Dixit VM. Deubiquitinase USP9X stabilizes MCL1 and promotes tumour cell survival. Nature. 2010; 463(7277):103-107.

50. Bignell GR, Warren W, Seal S, Takahashi M, Rapley E, Barfoot R, Green H, Brown C, Biggs PJ, Lakhani SR, 
Jones C, Hansen J, Blair E, Hofmann B, Siebert R, Turner G, et al. Identification of the familial cylindromatosis tumoursuppressor gene. Nature genetics. 2000; 25(2):160-165.

51. Lee EG, Boone DL, Chai S, Libby SL, Chien M, Lodolce JP and $\mathrm{Ma}$ A. Failure to regulate TNF-induced NF-kappaB and cell death responses in A20-deficient mice. Science (New York, NY). 2000; 289(5488):2350-2354.

52. Hershko A and Rose IA. Ubiquitin-aldehyde: a general inhibitor of ubiquitin-recycling processes. Proceedings of the National Academy of Sciences of the United States of America. 1987; 84(7):1829-1833.

53. Borodovsky A, Kessler BM, Casagrande R, Overkleeft HS, Wilkinson KD and Ploegh HL. A novel active site-directed probe specific for deubiquitylating enzymes reveals proteasome association of USP14. The EMBO journal. 2001; 20(18):5187-5196.

54. Kapuria V, Peterson LF, Fang D, Bornmann WG, Talpaz M and Donato NJ. Deubiquitinase inhibition by small-molecule WP1130 triggers aggresome formation and tumor cell apoptosis. Cancer research. 2010; 70(22):9265-9276.

55. Perry JW, Ahmed M, Chang KO, Donato NJ, Showalter HD and Wobus CE. Antiviral activity of a small molecule deubiquitinase inhibitor occurs via induction of the unfolded protein response. PLoS pathogens. 2012; 8(7):e1002783.

56. Chauhan D, Tian Z, Nicholson B, Kumar KG, Zhou B, Carrasco R, McDermott JL, Leach CA, Fulcinniti M, Kodrasov MP, Weinstock J, Kingsbury WD, Hideshima T, Shah PK, Minvielle S, Altun M, et al. A small molecule inhibitor of ubiquitin-specific protease-7 induces apoptosis in multiple myeloma cells and overcomes bortezomib resistance. Cancer cell. 2012; 22(3):345-358.

57. Fan YH, Cheng J, Vasudevan SA, Dou J, Zhang H, Patel RH, Ma IT, Rojas Y, Zhao Y, Yu Y, Zhang H, Shohet JM, Nuchtern JG, Kim ES and Yang J. USP7 inhibitor P22077 inhibits neuroblastoma growth via inducing p53-mediated apoptosis. Cell death \& disease. 2013; 4:e867.

58. Altun M, Kramer HB, Willems LI, McDermott JL, Leach CA, Goldenberg SJ, Kumar KG, Konietzny R, Fischer R, Kogan E, Mackeen MM, McGouran J, Khoronenkova SV, Parsons JL, Dianov GL, Nicholson B, et al. Activity-based chemical proteomics accelerates inhibitor development for deubiquitylating enzymes. Chemistry biology. 2011; 18(11):1401-1412.

59. Seiberlich V, Goldbaum O, Zhukareva V and RichterLandsberg C. The small molecule inhibitor PR-619 of deubiquitinating enzymes affects the microtubule network and causes protein aggregate formation in neural cells: implications for neurodegenerative diseases. Biochim Biophys Acta. 2012; 1823(11):2057-2068.

60. Liu CW and Jacobson AD. Functions of the 19S complex in proteasomal degradation. Trends in biochemical sciences. 2013; 38(2):103-110.

61. Yao $\mathrm{T}$ and Cohen RE. A cryptic protease couples deubiquitination and degradation by the proteasome. Nature. 2002; 419(6905):403-407.

62. Spataro V, Simmen K and Realini CA. The essential 26S proteasome subunit Rpn11 confers multidrug resistance to mammalian cells. Anticancer research. 2002; 22(6c):39053909.
63. Nabhan JF and Ribeiro P. The $19 \mathrm{~S}$ proteasomal subunit POH1 contributes to the regulation of c-Jun ubiquitination, stability, and subcellular localization. The Journal of biological chemistry. 2006; 281(23):16099-16107.

64. Gallery M, Blank JL, Lin Y, Gutierrez JA, Pulido JC, Rappoli D, Badola S, Rolfe M and Macbeth KJ. The JAMM motif of human deubiquitinase Poh1 is essential for cell viability. Molecular cancer therapeutics. 2007; 6(1):262-268.

65. Lee MJ, Lee BH, Hanna J, King RW and Finley D. Trimming of ubiquitin chains by proteasome-associated deubiquitinating enzymes. Molecular \& cellular proteomics: MCP. 2011; 10(5):R110.003871.

66. Koulich E, Li X and DeMartino GN. Relative structural and functional roles of multiple deubiquitylating proteins associated with mammalian 26S proteasome. Molecular biology of the cell. 2008; 19(3):1072-1082.

67. Hanna J, Hathaway NA, Tone Y, Crosas B, Elsasser S, Kirkpatrick DS, Leggett DS, Gygi SP, King RW and Finley D. Deubiquitinating enzyme Ubp6 functions noncatalytically to delay proteasomal degradation. Cell. 2006; 127(1):99-111.

68. Jin YN, Chen PC, Watson JA, Walters BJ, Phillips SE, Green K, Schmidt R, Wilson JA, Johnson GV, Roberson ED, Dobrunz LE and Wilson SM. Usp14 deficiency increases tau phosphorylation without altering tau degradation or causing tau-dependent deficits. PloS one. 2012; 7(10):e47884.

69. Chen PC, Bhattacharyya BJ, Hanna J, Minkel H, Wilson JA, Finley D, Miller RJ and Wilson SM. Ubiquitin homeostasis is critical for synaptic development and function. The Journal of neuroscience: the official journal of the Society for Neuroscience. 2011; 31(48):17505-17513.

70. Jung H, Kim BG, Han WH, Lee JH, Cho JY, Park WS, Maurice MM, Han JK, Lee MJ, Finley D and Jho EH. Deubiquitination of Dishevelled by Usp14 is required for Wnt signaling. Oncogenesis. 2013; 2:e64.

71. Huranova M, Hnilicova J, Fleischer B, Cvackova Z and Stanek D. A mutation linked to retinitis pigmentosa in HPRP31 causes protein instability and impairs its interactions with spliceosomal snRNPs. Human molecular genetics. 2009; 18(11):2014-2023.

72. Wu N, Liu C, Bai C, Han YP, Cho WC and Li Q. OverExpression of Deubiquitinating Enzyme USP14 in Lung Adenocarcinoma Promotes Proliferation through the Accumulation of beta-Catenin. International journal of molecular sciences. 2013; 14(6):10749-10760.

73. Wu N, Zhang C, Bai C, Han YP and Li Q. MiR-4782-3p inhibited non-small cell lung cancer growth via USP14. Cellular physiology and biochemistry: international journal of experimental cellular physiology, biochemistry, and pharmacology. 2014; 33(2):457-467.

74. Mialki RK, Zhao J, Wei J, Mallampalli DF and Zhao Y. Overexpression of USP14 protease reduces I-kappaB protein levels and increases cytokine release in lung epithelial cells. The Journal of biological chemistry. 2013; 288(22):15437-15441.

75. Yao T, Song L, Xu W, DeMartino GN, Florens L, Swanson SK, Washburn MP, Conaway RC, Conaway JW and Cohen RE. Proteasome recruitment and activation of the Uch37 deubiquitinating enzyme by Adrm1. Nature cell 
biology. 2006; 8(9):994-1002.

76. Schreiner P, Chen X, Husnjak K, Randles L, Zhang N, Elsasser S, Finley D, Dikic I, Walters KJ and Groll M. Ubiquitin docking at the proteasome through a novel pleckstrin-homology domain interaction. Nature. 2008; 453(7194):548-552.

77. Chen X, Lee BH, Finley D and Walters KJ. Structure of proteasome ubiquitin receptor $\mathrm{hRpn} 13$ and its activation by the scaffolding protein hRpn2. Molecular cell. 2010; 38(3):404-415.

78. Mazumdar T, Gorgun FM, Sha Y, Tyryshkin A, Zeng S, Hartmann-Petersen R, Jorgensen JP, Hendil KB and Eissa NT. Regulation of NF-kappaB activity and inducible nitric oxide synthase by regulatory particle non-ATPase subunit 13 (Rpn13). Proceedings of the National Academy of Sciences of the United States of America. 2010; 107(31):13854-13859.

79. Wicks SJ, Haros K, Maillard M, Song L, Cohen RE, Dijke PT and Chantry A. The deubiquitinating enzyme UCH37 interacts with Smads and regulates TGF-beta signalling. Oncogene. 2005; 24(54):8080-8084.

80. Ko YM, Chang CY, Chiou SJ, Hsu FJ, Huang JS, Yang YL, Guh JY and Chuang LY. Ubiquitin C-terminal hydrolase-L5 is required for high glucose-induced transforming growth factor-beta receptor I expression and hypertrophy in mesangial cells. Archives of biochemistry and biophysics. 2013; 535(2):177-186.

81. Chen Z, Niu X, Li Z, Yu Y, Ye X, Lu S and Chen Z. Effect of ubiquitin carboxy-terminal hydrolase 37 on apoptotic in A549 cells. Cell biochemistry and function. 2011; 29(2):142-148.

82. Fang $\mathrm{Y}, \mathrm{Fu} \mathrm{D}$, Tang W, Cai Y, Ma D, Wang H, Xue R, Liu T, Huang X, Dong L, Wu H and Shen X. Ubiquitin C-terminal Hydrolase 37, a novel predictor for hepatocellular carcinoma recurrence, promotes cell migration and invasion via interacting and deubiquitinating PRP19. Biochimica et biophysica acta. 2013; 1833(3):559-572.

83. Lee BH, Lee MJ, Park S, Oh DC, Elsasser S, Chen PC, Gartner C, Dimova N, Hanna J, Gygi SP, Wilson SM, King RW and Finley D. Enhancement of proteasome activity by a small-molecule inhibitor of USP14. Nature. 2010; 467(7312):179-184.

84. Xu YH and Guo NL. USP14 inhibitor IU1 prevents ventilatorinduced lung injury in rats. Cellular and molecular biology (Noisy-le-Grand, France). 2014; 60(2):50-54.

85. Nag DK and Finley D. A small-molecule inhibitor of deubiquitinating enzyme USP14 inhibits Dengue virus replication. Virus research. 2012; 165(1):103-106.

86. Finley DJ, King RK, Lee BH, Lee MJ and Gahman TC. Tricycle proteasome activity enhancing compounds. United States Patent NO 20130210845A1.

87. D’Arcy P, Brnjic S, Olofsson MH, Fryknas M, Lindsten K, De Cesare M, Perego P, Sadeghi B, Hassan M, Larsson R and Linder S. Inhibition of proteasome deubiquitinating activity as a new cancer therapy. Nature medicine. 2011; 17(12):1636-1640.

88. Tian Z, D'Arcy P, Wang X, Ray A, Tai YT, Hu Y, Carrasco RD,
Richardson P, Linder S, Chauhan D and Anderson KC. A novel small molecule inhibitor of deubiquitylating enzyme USP14 and UCHL5 induces apoptosis in multiple myeloma and overcomes bortezomib resistance. Blood. 2014; 123(5):706-716.

89. Feng X, Holmlund T, Zheng C and Fadeel B. Proapoptotic effects of the novel proteasome inhibitor b-AP15 on multiple myeloma cells and natural killer cells. Experimental hematology. 2014; 42(3):172-182.

90. Sarhan D, D'Arcy P and Lundqvist A. Regulation of TRAIL-receptor expression by the ubiquitin-proteasome system. International journal of molecular sciences. 2014; 15(10):18557-18573.

91. Sarhan D, Wennerberg E, D'Arcy P, Gurajada D, Linder S and Lundqvist A. A novel inhibitor of proteasome deubiquitinating activity renders tumor cells sensitive to TRAIL-mediated apoptosis by natural killer cells and T cells. Cancer immunology, immunotherapy: CII. 2013; 62(8):1359-1368.

92. Wang X, Stafford W, Mazurkiewicz M, Fryknas M, Brjnic S, Zhang X, Gullbo J, Larsson R, Arner ES, D'Arcy $\mathrm{P}$ and Linder S. The 19S Deubiquitinase inhibitor b-AP15 is enriched in cells and elicits rapid commitment to cell death. Molecular pharmacology. 2014; 85(6):932-945.

93. Linder $\mathrm{S}$ and Larsson R. Method for inhibition of deubiquitinating actiity. United States Patent NO 201402283 $54 \mathrm{~A} 1$

94. Zhou B, Zuo Y, Li B, Wang H, Liu H, Wang X, Qiu X, Hu Y, Wen S, Du J and Bu X. Deubiquitinase inhibition of $19 \mathrm{~S}$ regulatory particles by 4-arylidene curcumin analog $\mathrm{AC} 17$ causes NF-kappaB inhibition and p53 reactivation in human lung cancer cells. Molecular cancer therapeutics. 2013; 12(8):1381-1392.

95. Zhang JJ, Ng KM, Lok CN, Sun RW and Che CM. Deubiquitinases as potential anti-cancer targets for gold(III) complexes. Chemical communications (Cambridge, England). 2013; 49(45):5153-5155.

96. Liu N, Liu C, Li X, Liao S, Song W, Yang C, Zhao C, Huang H, Guan L, Zhang P, Liu S, Hua X, Chen X, Zhou P, Lan X, Yi S, et al. A novel proteasome inhibitor suppresses tumor growth via targeting both 19S proteasome deubiquitinases and $20 \mathrm{~S}$ proteolytic peptidases. Scientific reports. 2014; 4:5240.

97. Liu N, Li X, Huang H, Zhao C, Liao S, Yang C, Liu S, Song W, Lu X, Lan X, Chen X, Yi S, Xu L, Jiang L, Zhao C, Dong $X$, et al. Clinically used antirheumatic agent auranofin is a proteasomal deubiquitinase inhibitor and inhibits tumor growth. Oncotarget. 2014; 5(14):5453-5471.

98. Groth Petersen D, Dahllof I and Nielsen LP. Effects of zinc pyrithione and copper pyrithione on microbial community function and structure in sediments. Environmental toxicology and chemistry/SETAC. 2004; 23(4):921-928.

99. Chen X, Shi X, Zhao C, Li X, Lan X, Liu S, Huang H, Liu N, Liao S, Zang D, Song W, Liu Q, Carter BZ, Dou QP, Wang $X$ and Liu J. Anti-rheumatic agent auranofin induced apoptosis in chronic myeloid leukemia cells resistant to imatinib through both Bcr/Abl-dependent and -independent mechanisms. Oncotarget. 2014; 5(19):9118-9132. 